\title{
Pengaruh Sikap Bahasa, Minat dan Intensitas Bermedsos Terhadap Hasil Belajar Bahasa Bali Pada Siswa SMA
}

\author{
I Made Werdiatmaja \\ Program Studi Pendidikan Bahasa, Program Pascasarjana Undiksha \\ Email: werdiatmaja007@gmail.com \\ I Made Sutama \\ Program Studi Pendidikan Bahasa, Program Pascasarjana Undiksha \\ Email: made.sutama@pasca.undiksha.ac.id \\ I Wayan Rasna \\ Program Studi Pendidikan Bahasa, Program Pascasarjana Undiksha \\ Email:wayan.rasna@pasca.undiksha.ac.id
}

\begin{abstract}
Abstrak
Penelitian ini bertujuan untuk mengetahui seberapa besar pengaruh sikap bahasa, minat dan intensitas bermedsos terhadap hasil belajar Bahasa Bali pada siswa kelas XI Bahasa SMA Negeri 4 Singaraja. Rancangan penelitian ini adalah ex-post facto dengan sampel sebanyak 72 orang. Pengumpulan data menggunakan metode kuesioner dan metode tes. Data dianalisis dengan teknik analisis regresi ganda. Hasil penelitian menunjukkan bahwa sikap bahasa, minat belajar, serta intensitas bermedsos berpengaruh secara signifikan terhadap hasil belajar Bahasa Bali siswa di SMA Negeri 4 Singaraja. Hal tersebut dapat terlihat dari hasil uji parsial variabel sikap bahasa diperoleh thitung 3,752 dengan nilai signifikansi 0,000, variabel minat belajar diperoleh thitung 3,351 dengan nilai signifikansi 0,001, serta variabel intensitas bermedsos diperoleh thitung 4,541 dengan nilai signifikansi 0,000 . Simpulan dari penelitian ini adalah adanya pengaruh yang signifikan sikap bahasa, minat dan intensitas bermedsos terhadap hasil belajar Bahasa Bali pada siswa kelas XI Bahasa SMA Negeri 4 Singaraja. Dengan adanya penelitian ini diharapkan penanaman sikap bahasa yang positif, pendekatan yang inovatif dan penggunaan media sosial lebih ditingkatkan agar hasil belajar Bahasa Bali siswa juga meningkat.
\end{abstract}

Kata kunci: sikap , minat, medsos, hasil belajar

\begin{abstract}
This research aims to know how much the influence of language attitude, interest and social media intensity to the results of Balinese language learning In XI high School foreign language 4 Singaraja. This research draft is an ex-post facto research that uses sample of 72 people. Methods of collecting data in this study using questionnaire methods and test methods. Data analysed with double regression analysis techniques. The results of the study showed that language attitudes, interest and social media intensity have significant effect on the results of balinese language students in high school 4 Singaraja. It can be seen from the test results of partial variable language attitudes gained tcount 3,752 value of significance 0,000 , variable interest learn acquired tcount 3,351 value of significance 0,001 , as well social media intensity variables acquired tcount 4,541 value of significance 0,000 . The conclusion of this study is the significant influence of language attitudes, interest and intensity of social media to the outcome of Balinese language In XI high School foreign language 4 Singaraja. With this research is expected to grow a positive language attitude, innovative approach and the use of social media is improved so that the results of language learning is also increased.
\end{abstract}

Keyword: languagea ttitudes, interest, Med, learning outcomes

\section{Pendahuluan}

Bali merupakan salah satu daerah di Indonesia yang memiliki bahasa daerah beserta aksaranya, yakni bahasa dan aksara Bali. Kenyataan ini merupakan suatu kebanggaan yang patut disyukuri karena hanya sedikit bahasa-bahasa di belahan dunia yang memiliki kelengkapan aspek ini. Sebagai bahasa Daerah, bahasa Bali dapat dikatakan bersifat istimewa, karena bahasa Bali mempunyai huruf tersendiri yaitu "Aksara Bali" di samping huruf latin Bali yang telah ditetapkan ejaannya oleh Mendikbud dengan SK No.074/U/1974 bersama dengan penetapan Ejaan Bahasa Daerah Sunda dan Bahasa Jawa (Panitia Penyusun Bahasa daerah Bali, 1978). bahasa Bali mempunyai kedudukan yang sangat penting dalam kehidupan budaya masyarakat Bali dan berfungsi: 1) dalam kehidupan nyastra; 2) sebagai wahana seni budaya Bali; dan 3) sebagai sarana pendidikan adat istiadat agama Hindu. Hal ini harus dilestarikan, dipertahankan dan dimantapkan pemahamannya di masyarakat. dalam mempertahankan sebuah bahasa. Adapun aspek-aspek yang dibutuhkan untuk menunjang hal tersebut, yaitu sikap bahasa. Sikap bahasa merupakan posisi mental atau perasaan terhadap bahasa sendiri atau bahasa orang lain (Kridalaksana, 2001:197). Dalam bahasa Indonesia kata sikap dapat mengacu pada bentuk tubuh, posisi 
berdiri yang tegak, perilaku atau gerak-gerik, dan perbuatan atau tindakan yang dilakukan berdasarkan pandangan (pendirian, keyakinan, atau pendapat) sebagai reaksi atas adanya suatu hal atau kejadian. Sikap merupakan fenomena kejiwaan, yang biasanya termanifestasi dalam bentuk tindakan atau perilaku. Sikap tidak dapat diamati secara langsung. Untuk mengamati sikap dapat dilihat melalui perilaku, tetapi berbagai hasil penelitian menunjukkan bahwa apa yang nampak dalam perilaku tidak selalu menunjukkan sikap. Begitu juga sebaliknya, sikap seseorang tidak selamanya tercermin dalam perilakunya. Anderson (1974) membagi sikap atas dua macam, yaitu (1) sikap kebahasaan dan (2) sikap nonkebahasaan. Sikap kebahasan dapat dikategorikan menjadi dua sikap yaitu sikap positif dan sikap negatif. Sikap positif yaitu sikap antusiasme terhadap penggunaan bahasanya (bahasa yang digunakan oleh kelompoknya/masyarakat tutur dimana dia berada). Sebaliknya jika ciri-ciri itu sudah menghilang atau melemah dari diri seseorang atau dari diri sekelompok orang anggota masyarakat tutur, maka berarti sikap negatif terhadap suatu bahasa telah melanda diri atau kelompok orang itu. Garvin dan Mathiot (1968) merumuskan tiga ciri sikap bahasa yaitu kesetiaan bahasa (language loyalty), kebanggaan bahasa (language pride), kesadaran adanya norma bahasa (awareness of the norm).

Dewasa ini penggunaan bahasa Bali dikalangan masyarakat Bali sendiri dirasa kurang begitu antusias. Hal ini merupakan tanda-tanda mulai munculnya sikap yang kurang positif terhadap bahasa tersebut. Bahasabahasa daerah terkadang dianggap sebagai bahasa yang kurang fleksibel dan kurang mengikuti perkembangan jaman. Demikian pula bahasa Bali. Anak-anak muda pada jaman sekarang kurang begitu mengerti dan antusias menggunakan bahasa tersebut, karena ada yang merasa bahwa bahasa Bali terlalu rumit bagi mereka, banyak leksikon dari bahasa Bali yang tidak dimengerti, ditambah dengan penggunaan tingkat tutur bahasa Bali dan sebagainya. Hal tersebut merupakan indikasi bahwa mereka sudah tidak berminat lagi untuk mempelajari bahasa Bali, atau hal itu juga dipengaruhi oleh perkembangan keadaan yang menghendaki segala sesuatu yang serba praktis dan simpel. Tidak hanya bahasa daerah. Sikap negatif juga akan lebih terasa akibat-akibatnya apabila seseorang atau sekelompok orang tidak mempunyai kesadaran akan adanya norma bahasa. Sikap tersebut nampak dalam tindak tuturnya. Mereka tidak merasa perlu untuk menggunakan bahasa secara cermat dan tertib, mengikuti kaidah yang berlaku. Dari perspektif sosiolinguistik fenomena sikap bahasa (language attitude) dalam masyarakat multibahasa merupakan gejala yang menarik untuk dikaji, karena melalui sikap bahasa dapat menentukan keberlangsungan hidup suatu bahasa.

Di era globalisasi ini perkembangan teknologi, informasi dan komunikasi semakin pesat. Dalam hal ini perkembangan-perkembangan teknologi kebanyakan menggunakan bahasa asing, sehingga hal ini mendorong para penutur lebih dominan memakai ataupun mempelajari bahasa asing ketimbang bahasanya sendiri, dengan tujuan agar dapat dengan mudah memahami dan mengaplikasikan teknologi tersebut. sedangkan dalam perkembangan komunikasi, para penutur lebih memilih menggunakan bahasa asing ataupun bahasa Indonesia. Hal ini dikarenakan para penutur terlihat lebih percaya diri ataupun lebih terpelajar jika menggunakan bahasa asing ataupun bahasa Indonesia ketimbang berkomunikasi menggunakan bahasa daerahnya yang dalam hal ini adalah bahasa Bali.

Secara tidak langsung keadaan ini semakin mendorong bahasa Bali kearah yang negatif dan semakin memperihatinkan. Misalnya saja para penutur yang aktif menggunakan media sosial atau yang sering disebut netizen("internet" dan "citizen"). Kebanyakan para penutur di media sosial, jika membuat status, mengomentari sesuatu ataupun menulis sesuatu lebih menggunakan bahasa asing ataupun bahasa Indonesia. Hal ini dikarenakan para netizen merasa lebih keren, meyakinkan ataupun lebih percaya diri dalam menggunakan bahasa tersebut ketimbang menggunakan bahasa daerah khususnya bahasa Bali yang dipandang katrok, tidak kekinian ataupun tidak menuruti jaman. Keadaan ini pastilah sudah jauh dari harapan. Bahasa Bali merupakan bahasa pertama ataupun bahasa ibu yang seharusnya digunakan sebagai alat komunikasi yang utama dalam kehidupan seharihari. Penulis berharap para penutur khususnya di wilayah Bali lebih banyak menggunakan bahasa Bali, karena kalau bukan kita yang melestarikan bahasa Bali, siapa lagi yang akan melestarikannya.

Kenyatan di lapangan menunjukkan hal yang sebaliknya, khususnya dikalangan para pelajar nilai ulangan harian begitu pula dalam ulangan umum bahasa Bali, banyak siswa mendapatkan nilai yang kurang memuaskan atau dibawah standar KKM yang telah ditentukan. Hal ini peneliti dapatkan pada saat menjadi guru dan sebagai penyuluh bahasa Bali. Di samping itu, hal yang lebih mencengangkan yang didapat oleh peneliti, pada saat peneliti menanyakan pembelajaran apa kiranya yang paling susah menurut peserta didik. Peneliti kira peserta didik akan menjawab Matematika, Kimia ataupun yang lainnya, namun peserta didik menjawab dengan jelas pembelajaran yang paling susah adalah bahasa Bali. Padahal siswa yang mengikuti ulangan, test ataupun pembelajaran bukanlah siswa asing, melainkan siswa Bali yang lahir dan dibesarkan di Bali, yang merupakan penutur sejati bahasa Bali, berkomunikasi menggunakan bahasa Bali. Di samping itu, mereka juga mengenal kebudayaan, masyarakat, dan lingkungannya. Dengan demikian, dapat dikatakan penguasaan kosakata bahasa Bali, pengungkapkan, dan konteks penggunaannya membentuk sebuah pengalaman bahasa. Unsur pengalaman bahasa ini merupakan skemata yang membentuk sebuah latar pengetahuan bahasa. Secara teoritis latar yang telah dimiliki tersebut akan memberikan kemudahan dalam mempelajari bahasa karena belajar merupakan sebuah proses menyatukan informasi baru dengan pengetahuan lama. Dengan kata lain, pembelajar menggabungkan informasi baru dengan yang telah diketahui. 
Dari berbagai penyebab dan masalah yang terjadi yang terjadi di dalam pembelajaran Bahasa Bali maka penelitian ini memiliki batasan kajian. Penelitian ini dibatasi pada kajian sikap bahasa, minat dan intensitas bermedsos di kelas XI Bahasa SMA Negeri 4 Singaraja terhadap bahasa Bali. Sikap bahasa yang dimaksudkan dalam penelitian ini adalah sikap subjek terhadap bahasa Bali, apakah siswa merasa bangga ataupun senang terhadap Bahasa Bali ataupun sebaliknya. Selanjutnya, variabel sikap akan dicari pengaruhnya terhadap hasil belajar bahasa siswa pada mata pelajaran Bahasa Bali. Begitu pula halnya dengan minat dan intensitas bermedsos. Subjek penelitian ini adalah siswa kelas XI Bahasa SMA Negeri 4 Singaraja.

\section{Metode}

Jenis penelitian ini adalah penelitian kausal komparatif (Ex Post Facto). Penelitian Ex Post Facto artinya penelitian yang dilakukan untuk meneliti peristiwa yang telah terjadi yang kemudian merunut ke belakang untuk mengetahui faktor-faktor yang dapat menimbulkan kejadian tersebut. Menurut Emzir (2009) penelitian ex post facto adalah penyelidikan empiris yang sistematis di mana ilmuan tidak mengendalikan variabel bebas secara langsung karena perwujudan variabel tersebut telah terjadi atau karena variabel dalam penelitian tersebut tidak dapat dimanipulasi. Kemudian, penelitian ini menggunakan rancangan penelitian kuantitatif. Penelitian kuantitatif menekankan analisisnya pada data-data berupa angka yang diolah dengan metode statistik (Purwanto, 2010:167). Dalam penelitian ini, sikap bahasa siswa, minat dan intensitas bermedsos siswa serta hubungan antara sikap bahasa, minat dan intensitas bermedsos terhadap hasil belajar bahasa Bali menjadi kajiannya. Populasi penelitian ini adalah seluruh siswa Kelas XI Bahasa SMA Negeri 4 Singaraja yang terdiri dari kelas XI Bahasa 1 dan kelas XI Bahasa 2.

Dalam penelitian ini digunakan ukuran sampel sebanyak 72 orang dari seluruh jumlah kelas XI Bahasa yang ada di SMA Negeri 4 Singaraja. Hal ini dikarenakan jumlah populasi yang sedikit, sehingga keseluruhan populasi penelitian digunakan sebagai sampel penelitian. Berdasarkan rumusan hipotesis sebagaimana dinyatakan sebelumnya, variabel utama yang diukur dalam penelitian ini melibatkan tiga kelompok variabel bebas (X). Variabel tersebut adalah X1 (variabel sikap bahasa), yaitu sikap terhadap bahasa Bali, X2 (Variabel Minat), yaitu minat belajar terhadap bahasa Bali, X3 (Intensitas bermedsos), yaitu pengaruh intensitas bermedsos terhadap hasil belajar bahasa Bali. Variabel ini diperlakukan sebagai variabel bebas karena diduga memengaruhi hasil belajar siswa. Dengan demikian, variabel hasil belajar dalam penelitian ini adalah variabel terikat (Y) karena variabel hasil belajar diduga dipengaruhi oleh variabel sikap (X1), variabel minat (X2) dan variabel intensitas bermedsos (X3).

Dalam penelitian ini, mengenai metode pengumpulan data yang digunakan metode kuesioner (angket), dan metode tes. Data sikap bahasa, minat belajar, dan intensitas bermedsos siswa dikumpulkan dengan metode kuesioner yang telah diuji validitasnya. Sedangkan hasil belajar siswa dikumpulkan dengan menggunakan metode tes. Kegiatan analisis data meliputi kegiatan pengolahan data dan analisis statistik. Kegiatan analisis data meliputi :1) menyunting data secara manual dilakukan karena ada data yang tidak jelas atau kesalahan dalam pengisian instrumen sehingga tidak memenuhi syarat untuk dianalisis, 2) mentabulasi data, 3) mengolah data dalam bentuk yang sesuai dengan kebutuhan. Keseluruhan data kuantitatif yang terkumpul dalam penelitian ini dianalisis dengan teknik analisis deskriptif dan korelasional inferensial.

Untuk menguji hipotesis yang telah dirumuskan, terlebih dahulu dilakukan analisis data yang telah dikumpulkan. Dalam melakukan analisis data untuk penelitian ini ada tiga tahap yang harus dilalui, yaitu : 1) tahap deskripsi data, 2) tahap pengujian persyaratan analisis, dan 3) pengujian hipotesis.

\section{Hasil dan Pembahasan}

Dengan tujuan mendeskripsikan dan menguji pengaruh dari setiap variable bebas terhadap variable terikat, maka deskripsi data dari masing-masing variabel akan disajikan terlebih dahulu. Adapun informasi yang disajikan pada sub bab ini meliputi mean, median, mode dan standar deviasi dari masing-masing variabel penelitian. Selain itu, distribusi masing-masing variabel juga akan disajikan secara rinci.

Berdasarkan hasil tes dapat terlihat bahwa hampir setengah, yakni 45,8\%, siswa SMA 4 Singaraja memperoleh hasil belajar bahasa Bali sedang. Dapat dilihat pula bahwa 23,6\% siswa lainnya memperoleh hasil belajar yang tinggi. Presentase yang mendekati, yakni 20,8\%, merupakan presentase siswa yang memperoleh hasil belajar rendah, dan bahkan terdapat $9,7 \%$ siswa yang mendapat nilai sangat rendah. Dari data tersebut dapat dilihat bahwa hasil belajar Bahasa Bali siswa di sekolah tersebut sangat bervariatif. Untuk sikap bahasa hasil yang didapatkan yakni, 58,3\% memiliki sikap bahasa sedang, namun 34,7\% lainnya memiliki sikap bahasa yang tinggi. Hanya $6,9 \%$ atau 5 siswa yang memiliki sikap bahasa rendah terhadap bahasa Bali. Untuk minat belajar secara presentase, dapat dilihat bahwa $11,1 \%$ responden memiliki minat belajar bahasa Bali yang rendah. Namun presentasi tersebut jauh lebih kecil jika dibandingkan dengan presentase siswa yang memiliki minat belajar tinggi, yakni 37,8\%. Sama seperti perolehan data variabel bebas sebelumnya, pada variabel minat belajar, lebih dari setengah jumlah responden memiliki minat belajar yang sedang, yakni $61,1 \%$, dan untuk intensitas bermedsos dari hasil kuesioner, dapat terlihat bahwa hanya 4,1\% siswa yang memiliki intensitas bermedsos yang 
rendah. Presentase yang cukup mendekati hasil perolehan variabel sebelumnya pun ditemukan, dimana $68,1 \%$ siswa memiliki intesitas bermedsos yang sedang dan 37,8\% sisanya memiliki intensitas bermedsos yang tinggi.

Sebelum melakukan analisis regresi berganda untuk melihat pengaruh ketiga variabel bebas terhadap variabel terikat secara bersama-sama, analisis pengaruh setiap variabel bebas secara parsial dilakukan terlebih dahulu. Pengujian hipotesis secara parsial ini dimaksudkan untuk menguji keberartian pengaruh masing-masing variabel bebas yaitu sikap bahasa (X1), minat belajar (X2), dan intensitas bermedsos (X3) terhadap hasil belajar bahasa Bali (Y). Hasil analisis regresi selengkapnya dapat dilihat pada output SPSS 24 berikut ini.

Tabel 1. Hasil Uji Parsial

\begin{tabular}{|c|c|c|c|c|c|c|c|c|}
\hline \multicolumn{9}{|c|}{ Coefficients $^{\mathrm{a}}$} \\
\hline \multirow[b]{2}{*}{ Model } & & \multicolumn{2}{|c|}{ Unstandardized Coefficients } & \multicolumn{3}{|l|}{$\begin{array}{c}\text { Standardized } \\
\text { Coefficients }\end{array}$} & \multicolumn{2}{|c|}{ Collinearity Statistics } \\
\hline & & B & Std. Error & Beta & $\mathbf{t}$ & Sig. & Tolerance & VIF \\
\hline \multirow[t]{4}{*}{1} & (Constant) & $-25,350$ & 4,334 & & $-5,849$ & 0,000 & & \\
\hline & Sikap Bahasa & 0,280 & 0,075 & 0331 & 3,752 & 0,000 & 0,172 & 5,808 \\
\hline & Minat Belajar & 0,243 & 0,073 & 0,327 & 3,351 & 0,001 & 0,141 & 7,079 \\
\hline & Intensitas Bermedsos & 0,382 & 0,084 & 0,341 & 4,541 & 0,000 & 0,238 & 4,194 \\
\hline a. Dep & pendent Variable: & elajar & & & & & & \\
\hline
\end{tabular}

Berdasarkan hasil uji parsial, pada Tabel 1.1 dapat dilihat masing-masing nilai t pada tiap variabel. Adapun interpretasi data tersebut akan dipaparkan sebagai berikut. Berdasarkan perhitungan pada yang terangkum pada Tabel 1.1, dapat dilihat bahwa diperoleh $t_{\text {hitung }} 3,752$ dengan signifikansi 0,000 untuk variabel sikap bahasa. Karena nilai signifikansi $<$ level of signifikan $(0,000<0,05)$ dan nilai $t_{\text {hitung }}>t_{\text {table }}(3,752>1.995)$, maka dapat disimpulkan bahwa secara parsial sikap bahasa berpengaruh terhadap hasil belajar bahasa Bali. Oleh karena itu, hipotesis yang berbunyi terdapat pengaruh sikap bahasa terhadap hasil belajar bahasa Bali siswa kelas XI Bahasa SMA Negeri 4 Singaraja diterima. Masih dengan melihat rangkuman hasil analisis pada Tabel 1.1, terkait variabel minat belajar, dapat dilihat bahwa diperoleh $t_{\text {hitung }}$ 3,351 dengan signifikansi 0,001. Karena nilai signifikansi < level of signifikan $(0,001<0,05)$ dan nilai $t_{\text {hitung }}>t_{\text {table }}(3,351>1.995)$, maka dapat disimpulkan bahwa secara parsial minat belajar bahasa berpengaruh terhadap hasil belajar Bahasa Bali. Oleh karena itu, hipotesis yang berbunyi terdapat pengaruh minat belajar bahasa terhadap hasil belajar bahasa Bali siswa kelas XI Bahasa SMA Negeri 4 Singaraja diterima. Untuk uji parsial variabel bebas terakhir adalah variabel intensitas bermedsos. Berdasarkan hasil analisis pada Tabel 1.1, ditemukan thitung 4,541 dengan signifikansi 0,000. Karena nilai signifikansi $<$ level of signifikan $(0,000<0,05)$ dan nilai $t_{\text {hitung }}>t_{\text {table }}(4,541>1.995)$, dapat disimpulkan bahwa secara parsial intensitas bermedsos siswa berpengaruh terhadap hasil belajar bahasa Bali. Oleh karena itu, hipotesis yang berbunyi terdapat pengaruh intensistas bermedsos terhadap hasil belajar bahasa Bali siswa kelas XI Bahasa SMA Negeri 4 Singaraja diterima.

Setelah pengujian regresi secara parsial telah dilakukam berikutnya akan dilihat pula apakah terdapat pengaruh antara seluruh variabel bebas terhadap variabel terikat secara simultan. Berdasarkan hasil perhitungan analisis regresi berganda dengan menggunakan program SPSS for Window Release 15 diperoleh persamaan regresi sebagai berikut.

Tabel 2. Hasil Uji Simultan

\begin{tabular}{llrrrrr}
\hline & & \multicolumn{1}{c}{ ANOVA $^{\text {a }}$} & & & \\
Model & Sum of Squares & df & Mean Square & F & Sig. \\
\hline 1 & Regression & 13125,869 & 3 & 4375,290 & 225,637 & ) $.000^{\text {b }}$ \\
& Residual & 1318,576 & 68 & 19,391 & & \\
& Total & 14444,444 & 71 & & & \\
\hline
\end{tabular}

a. Dependent Variable: Hasil Belajar

b. Predictors: (Constant), Intensitas Bermedsos, Sikap Bahasa, Minat Belajar

Jika melihat hasil uji simultan pada Table 2, terlihat bahwa nilai $F_{\text {hitung adalah 225,637 dengan }}$ level signifikansi 0,000. Karena nilai signifikansi $<$ level of signifikan $(0,000<0,05)$ dan nilai $t_{\text {hitung }}>$ $\mathrm{t}_{\text {table }}(225,637>2,737)$, dapat disimpulkan bahwa secara simultan, sikap bahasa, minat belajar, serta intensitas bermedsos siswa berpengaruh terhadap hasil belajar bahasa Bali.

Setelah menemukan hasil bahwa terdapat pengaruh variabel bebas terhadap variabel terikat baik secara parsial maupun secara simultan, berikutnya penting untuk melihat berapa persen pengaruh yang diberikan variabel bebas pada variabel terikat, baik secara simultan. Hasil hitung koefisien determinasi secara simultan dapat dilihat pada Tabel berikut. 
Tabel 3. Koefisien Determinasi

\begin{tabular}{crrrrr}
\hline \multicolumn{6}{c}{ Model Summary } \\
\hline Model & $\mathrm{R}$ & R Square & Adjusted R Square & $\begin{array}{r}\text { Std. Error of the } \\
\text { Estimate }\end{array}$ & Durbin-Watson \\
\hline 1 & $0,953^{\mathrm{a}}$ & 0,909 & 0,905 & 4,40350 & 1,942 \\
\hline
\end{tabular}

a. Predictors: (Constant), Intensitas Bermedsos, Sikap Bahasa, Minat Belajar

b. Dependent Variable: Hasil Belajar

Berdasarkan hasil analisis dari Tabel 1.3 di atas diperoleh adjusted $R$ square (R2) sebesar 0,905 yang berarti sikap bahasa, minat belajar, dan intensitas bermedsos siswa berpengaruh sebesar $90,9 \%$ terhadap variabel hasil belajar Bahasa Bali. Selebihnya 9,1\% variabel hasil belajar dipengaruhi oleh faktor lain di luar model regresi penelitian ini. Selain itu, berdasarkan hasil koefisien regresi yang dilakukan, terlihat pengaruh positif yang diberikan oleh sikap bahasa, minat belajar, serta intensitas bermedsos pada peningkatan hasil belajar. Hal tersebut dapat dimaknai bahwa jika sikap bahasa, minat belajar, dan intensitas bermedsos meningkat, atau diperbaiki, maka kemungkinan keberhasilan peningkatan hasil belajar bahasa Bali juga akan terjadi. Sebaliknya, anak-anak dengan sikap bahasa, minat belajar, serta intensitas bermedsos yang rendah, akan memperoleh hasil belajar yang rendah pula.

Dari analisis regresi secara parsial, sikap bahasa berpengaruh signifikan terhadap hasil belajar Bahasa Bali siswa. Sikap bahasa merupakan reaksi penilaian terhadap bahasa tertentu (Riana \& Setiadi, 2015). Dengan hasil penilaian yang positif terhadap sebuah bahasa, akan muncul motivasi yang positif pula dalam usaha penguasaannya. Hosseini \& Pourmandnia (2013) serta Prodromou (1992) dengan tegas mengungkap bahwa sikap bahasa yang positif merupakan salah satu faktor dalam keberhasilan pembelajaran bahasa. Meski Istiyani (2017) mengungkap strategi kognitif dan metkognitif siswa merupakan faktor pemerolehan prestasi belajar Bahasa siswa, namun modal utamanya tetap sikap positif terhadap Bahasa target.

Hasil belajar Bahasa Bali siswa SMA 4 Singaraja dipengaruhi secara signifikan oleh minat belajar. Slameto (2003) mengemukakan minat sebagai rasa lebih suka dan rasa ketertarikan pada suatu hal/ aktivitas, tanpa ada yang menyuruh. mencurahkan perhatiannya secara maksimal. Siswa yang memiliki minat tinggi terhadap pelajaran Bahasa Bali, sudah tentu akan selalu berusaha lebih untuk mencapai hasil belajar maksimal. Siswa tersebut akan aktif mencari bahan untuk belajar, bertanya jika menemukan kesulitan, serta berupaya memperbaiki kekurangan jika hasil belajar dirasa belum memuaskan. Hal tersebut didukung oleh pendapat Lestari (2013) yang menyatakan bahwa peserta didik yang memiliki minat belajar yang tinggi tidak akan menjadikan hambatan sebagai halangan dalam belajar. Dengan hasil analisis thitung 3,351 dan signifikansi level 0,001 , dapat disimpulkan bahwa dalam penelitian ini, pengaruh signifikan minat belajar terhadap hasil belajar Bahasa Bali telah terbukti.

Faktor terakhir yang ditemukan sebagai faktor yang berpengaruh signifikan dalam menentukan hasil belajar Bahasa Bali siswa pada penelitian ini adalah intensitas bermedsos. Dewasa ini, penggunaan media dalam belajar merupakan sesuatu yang dapat dijumpai dimana saja. Seperti yang diungkap oleh Arsyad (2013) media merupakan sesuatu yang tidak dapat dipisahkan dari proses belajar mengajar demi tercapainya suatu tujuan pendidikan dan tujuan pembelajaran. Media internet sebagai bagian dari jenis pengembangan media pembelajaran yang telah memiliki berbagai macam fasilitas yang dapat membantu penggunannya dalam mengerjakan sesuatu dan mencari informasi yang diinginkan. Salah satu fasilitasnya, yaitu media sosial yang memberikan ruang untuk berinteraksi antar manusia tanpa mengenal jarak dan waktu. Boyd dan Ellison (2008) mendefinisikan media sosial sebagai bentuk pelayanan berbasis web yang memungkinkan individu membuat profil pribadi, berbagi informasi, serta melihat dan melintasi profil orang-orang yang terdaftar dalam koneksi mereka.

Berdasarkan hasil analisis SPSS 24, diperoleh hasil thitung 4,541 dengan level signifikan sebesar 0,000. Hal tersebut menunjukkan adanya pengaruh positif dan signifikan dari intensitas bermedsos siswa SMA Negeri 4 Singaraja terhadap hasil belajar Bahasa Bali. Hasil tersebut sejalan dengan studi sebelumnya yang menemukan hubungan dan pengaruh signifikan dari penggunaan media sosial terhadap hasil belajar siswa SMA dan perguruan tinggi (remaja) (Wibisono\& Mulyani, 2018; Riyanti, 2016; Achmad, 2017; Masfufah, Annur, \& Mahardika, 2015; Himawan, 2017; Fidyastuti, 2013).

\section{Simpulan}

Berdasarkan data yang telah dikumpulkan dan di analisis dalam penelitian ini, dapat diambil 4 kesimpulan. 1) Sikap bahasa berperngaruh signifikan terhadap hasil belajar Bahasa Bali siswa SMA Negeri 4 Singaraja. 2) Minat belajar berpengaruh signifikan terhadap hasil belajar Bahasa Bali siswa SMA Negeri 4 Singaraja. 3) Intensitas Bermedsos berpengaruh signifikan terhadap hasil belajar Bahasa Bali siswa SMA Negeri 4 Singaraja. 4) Sikap bahasa, minat belajar, dan intensitas bermedsos memiliki pengaruh yang signifikan terhadap hasil belajar Bahasa Bali siswa SMA Negeri 4 Singaraja secara simultan sebesar 90,9\%. 
Hasil penelitian ini dapat dijadikan landasan untuk meningkatkan hasil belajar Bahasa Bali, dengan penanaman sikap yang positif terhadap Bahasa Bali sebagai Bahasa Target yang dipelajari, menggunakan pendekatan yang inovatif untuk lebih menarik minat belajar bahasa Bali siswa dan pemanfaatan media sosial sebagai media pembelajaran online di kalangan remaja ditingkatkan, agar pembelajaran Bahasa Bali menjadi jauh lebih baik

\section{Daftar Pustaka}

Achmad, A. (2017). Pengaruh Antara Penggunaan Media Sosial Terhadap Prestasi Belajar Pada Siswa SMA Negeri 1 Enrekang dan MA Muhammadiyah Kalosi, Kabupaten Enrekang Tahun Ajaran 2017/2018. Universitas Hasanudin: Makasar

Anderson, Edmund A. 1974. "Language Attitude, Belief, and Value: A Study in Linguistic Cognitive Frame Works". Georgetown University.

Arsyad, A. (2013). Media Pembelajaran. Jakarta: PT Raja Grafindo.

Boyd, D. M \& Ellison, B.N. 2008. Social Network Sites: Defintion, History and Scholarship. Journal of Computer-Mediated Communication. Vol. 13. Issue 1

Emzir. 2009. Metodologi Penelitian Pendidikan. Jakarta: Rajawali Press.

Fidyastuti, M.N. 2013. Hubungan intensitas penggunaan situs jejaring social Facebook dengan prestasi belajar mahasiswa D IV bidan Pendidikan STIKES 'Aisyiyah Yogyakarta Tahun 2013. Sekolah Tinggi Ilmu Kesehatan 'Aisyiyah: Yogyakarta

Garvin, P.L dan Mathiot M. 1968. "The Urbanization of the Guarani Language : Problem in Language and Culture" dalam Chaer (ed) 2004.

Himawan, A.A. (2017). Pengaruh Penggunaan Media Sosial dan intensitas Menonton Drama Televisi terhadap Hasil Belajar Siswa pada Mata Pelajaran Pemrograman Dasar Kelas X TKJ SMK Batik 1 Surakarta. Universitas Sebelas Maret: Surakarta

Hosseini, S.B. \& Pourmandnia, D. (2013). Language Learners' Attitudes and Beliefs: Brief Review of the Related Literature and Frameworks. International Journal on New Trends in Education and Their Implications. 4(4), pp 16-74

Istiyani, E. (2014). Second Language Learners' Attitudes and Strategies in Learning English as a Foreign Language. Jurnal Penelitian Humaniora, 15(2), pp 99-110

Kridalaksana, Harimurti. 2001. Fungsi Bahasa dan Sikap Bahasa. Flores: Nusa Indah

Lestari, I. 2013. Pengaruh Waktu Belajar dan Minat Belajar terhadap Hasil Belajar Matematika. Formatif, 3 (2), pp 115-125.

Masfufah, Annur, S., \& Mahardika, A.I. (2015). Hubungan Keaktifan Penggunaan Media Sosial terhadap Hasil Belajar Fisika Siswa Kelas X dan XI IPA di SMA Negeri Banjarmasin. Berkala Ilmiah Pendidikan Fisika, 3(3), pp 230-241

Panitia Peneliti Naskah Ejaan Bahasa Bali. 1978. Ejaan Bahasa Daerah Bali yang Disempurnakan (Huruf Latin). Denpasar : Dinas Pengajaran Provinsi Bali.

Prodromou, L. (1992). What culture? Which culture? Cross-cultural factors in language learning. ELT Journal, 46(1), pp 39-50.

Purwanto. 2010. Evaluasi Hasil belajar. Yogyakarta: Pustaka Pelajar.

Riana, R. \& Setiadi, S. (2015). Pengaruh Sikap Berbahasa Terhadap Penerapan Bahasa Indonesia Dalam Penulisan Skripsi Mahasiswa Fakultas Ilmu Budaya, Universitas Diponegoro. J. DINAMIKA SOSBUD. 17(2), pp $104-116$

Riyanti, Y.A.V. (2016). Hubungan Intensitas Mengakses Sosial Media terhadap Perilaku Belajar Mata Pelajaran Produktif pada Siswa Kelas XI Jasa Boga di SMK 3 Klaten. Universitas Negeri Yogyakarta: Yogyakarta

Slameto. 2003. Belajar dan Faktor-faktor yang Mempengaruhinya. Yogya: Pustaka Pelajar.

Wibisono, T. \& Mulyani, Y.S. (2018). Analisis Dampak Penggunaan Media Sosial terhadap Prestasi Akademik Pelajar Tingkat Sekolah Menengah Pertama. Jurnal Ekonomi Manajemen, 4(1), pp 1-7 